\title{
Vacuum levels and milk-flow-dependent vacuum drops affect machine milking performance and teat condition in dairy cows
}

\author{
J. Besier and R. M. Bruckmaier ${ }^{1}$ \\ Veterinary Physiology, Vetsuisse Faculty, University of Bern, Bremgartenstr. 109a, 3012 Bern, Switzerland
}

\begin{abstract}
Different levels of claw vacuum during machine milking may influence milking performance and teat condition. The claw vacuum acts on the teat and is responsible for removal and transport of milk but is also causing potential effects on the teat tissue. In the absence of milk flow, the claw vacuum is similar as the system vacuum. During milk flow, the claw vacuum drops to lower levels depending on lifting height and tube length and diameter, which may influence milking performance and the mechanical load on the teat tissue. The goal of the present study was to investigate the effects of high system vacuum and extremely low claw vacuum during milk flow on milking performance and teat condition after milking recorded by ultrasound. Treatments were control (treatment 1) with a system vacuum of 42 and a minimum claw vacuum during milk flow of $33 \mathrm{kPa}$; treatment 2 representing a system vacuum of $50 \mathrm{kPa}$, with a minimum claw vacuum almost similar as treatment $1(34 \mathrm{kPa})$; and treatment 3 with the same system vacuum as treatment 1 but a claw vacuum drop during milk flow down to $24 \mathrm{kPa}$. Total milk yield was similar in all treatments, but strip yield was lower in treatment 3 than in the other treatments. Milk flow was similar in treatment 1 and treatment 2, but was reduced in treatment 3 , thus causing a prolonged milking time in treatment 3. Teat wall thickness was increased and teat cistern diameter was decreased in treatment 2 as compared with the other treatments. The results demonstrate that the minimum claw vacuum had the main influence on milking performance independent of the level of the system vacuum and related vacuum drops and a low minimum claw vacuum caused low milk flow and long milking times. Teat condition at the end of milking, however, was mainly dependent on the system vacuum, and the load on the teat tissue was obviously increased at a system vacuum of $50 \mathrm{kPa}$. This effect was obviously occurring toward the end of milking when milk flow decreased and hence the milk flow dependent
\end{abstract}

Received September 1, 2015.

Accepted December 13, 2015.

${ }^{1}$ Corresponding author: rupert.bruckmaier@vetsuisse.unibe.ch vacuum drop disappeared. Therefore, an early cluster detachment should be considered to avoid an increased effect on the teat tissue. Estimates of simulated early detachment levels in the present study of up to 1,000 $\mathrm{g} / \mathrm{min}$ lead to the assumption of minimal milk loss at simultaneously shorter machine-on time through the avoidance of lowest milk flow at the end of milking.

Key words: machine milking, vacuum, dairy cow

\section{INTRODUCTION}

During machine milking of dairy cows, the milk is removed by vacuum. The vacuum beneath the teat (claw vacuum) changes during the course of milking. In absence of milk flow, the claw vacuum is similar to the full system vacuum level, whereas it drops as soon as milk is present and transported and lifted in the milk tubes (Ambord and Bruckmaier, 2010). The degree of this vacuum drop depends on the technical characteristics of the milking system and increases with increasing milk flow rate. Highest vacuum drops occur in high line milking systems during the period of high milk flow rate (reviewed by Besier et al., 2016).

The pulsation chamber vacuum, which is controlled by the pulsator, does not change due to milk flow. Its primary function is the induction of opening and closing of the teat cup liner during evacuation and ventilation of the pulsation chamber, respectively. In turn, the vacuum at the teat end causes the removal of the milk from the teat while the liner is open, induces the collapse of the liner during ventilation of the pulsation chamber, and hence massages the teat tissue during the liner-closed phase. As a consequence, a drop of the claw vacuum during milking may not only reduce milking performance through reduced efficiency of milk removal (Rasmussen and Madsen, 2000) but can also compromise the teat condition due to an impaired liner closure and reduced pressure of the liner on the teat and hence a reduced massage effect of the closed liner on the teat (Hamann et al., 1993). The effect of low teat end vacuum on the liner movement within each pulsation cycle leads to a prolonged liner-open phase because the liner opens earlier during the evacuation phase of the pulsation chamber and closes later when 
the pulsation chamber is ventilated (Spencer and Jones, 2000). In addition, a drop of the claw vacuum may increase the probability of liner slips because the adhesion of the liner to the teat is reduced (Baxter et al., 1950; Stewart and Schultz, 1958; Rasmussen and Madsen, 2000; Besier et al., 2016). Milk flow dependent vacuum drops cannot completely be avoided with the currently available milking systems, because the milk tube is responsible for both, vacuum provision on the teat and transport of the removed milk. However, no scientific evidence is available that vacuum drops should be completely avoided as long as the remaining vacuum is high enough to close the liner adequately. To allow a minimum claw vacuum during maximum milk flow and vacuum drop, the system vacuum has to be adjusted to an appropriately high level. However, the vacuum drop does not occur during periods of no or low milk flow, causing the exposure of the teat to the full system vacuum at the start and end of milking. Because the milk flow usually increases fast at the start of milking after an adequate teat preparation, the exposure of the teat to the full system vacuum is short during early milking. The main exposure of the teat to high claw vacuum occurs toward the end of milking when milk flow declines or ceases sequentially in individual quarters, while potential vacuum drops disappear gradually. The main effect of a high system vacuum on the teat was shown to occur toward the end of milking (Isaksson and Lind, 1992). It is supposed that a high system vacuum causes an increased mechanical load on the teat tissue (Zecconi et al., 1992; Hamann et al., 1993; Rasmussen and Madsen, 2000) and incomplete udder emptying (Hamann et al., 1994). Some authors such as Mein et al. (1973a,b), Bothur and Wehowsky (1978), and Hamann (1989) discussed cluster climbing and deeper penetration of the teat into the teat cup liner due to a very high claw vacuum, especially at the end of milking. The existing scientific literature indicates that milk flow dependent vacuum drops should be kept at a moderate level to avoid high system vacuum settings and hence too high vacuum at the teat end in the absence of milk flow.

Comprehensive studies on different settings of system vacuum combined with different degrees of milk-flow-dependent vacuum drops considering milking performance as well as effects on the teat have to our knowledge not been published. The objective of the current study was to test the effect of an extreme milk-flow-dependent vacuum drop and a compensation of the resulting low teat end vacuum through a higher system vacuum on milking performance and teat condition after milking. Furthermore, on the basis of the recorded milk flow data, we estimated milking characteristics at different assumed detachment levels of 1,000, 800,600, and 400 $\mathrm{g} / \mathrm{min}$ to allow an assumption of milk loss on the one hand, but reduced machine-on time on the other hand through early cluster detachment.

\section{MATERIALS AND METHODS}

\section{Experimental Animals, Housing, and Milking}

Twelve dairy cows (9 Swedish Red and 3 Holstein) were used in this study. They were from 119 to 301 DIM of their first (5 animals), second (5 animals), or fourth (2 animals) lactation, respectively.

The mean 305-d milk production of the experimental herd was $9,000 \mathrm{~kg}$. The animals were kept in loose housing. Milking was performed in a tandem milking parlor. The cluster used in the trial was the Harmony Plus with the liner model 999009-82 (DeLaval, Tumba, Sweden) and a weight of $1.7 \mathrm{~kg}$. The inner diameter of the long milk tube was $16 \mathrm{~mm}$. The pulsator used in the experimental milking system was the EP 100 (DeLaval) at a pulsation rate of 60 cycles/min and a pulsation ratio of 65/35 (measured duration of phases: A 130, B 515, C 90, D $265 \mathrm{~ms}$, respectively), with a left-right alternating pulsation.

Throughout the experiment the cows were milked by the same person at 0530 and $1630 \mathrm{~h}$ (i.e., at 13- and 11-h milking intervals). The lag time from the first touch of the udder until cluster attachment was $1 \mathrm{~min}$ (forestripping and cleaning, manual teat stimulation). When milk flow dropped toward the end of milking to $<200 \mathrm{~g} / \mathrm{min}$, the milker started massaging the udder for machine stripping. As soon as milk flow rate decreased again below $200 \mathrm{~g} / \mathrm{min}$, the cluster was detached.

\section{Treatments}

Different system vacuum levels combined with different degrees of vacuum drops during peak milk flow rate were tested in 3 treatments. Each cow was milked at 6 successive milkings at each treatment, but the sequence of treatments was randomly varied between cows (crossover design). In treatment 1, a system vacuum of $42 \mathrm{kPa}$ was used. The vacuum drop at the teat end was adjusted to $9 \mathrm{kPa}$ at a milk flow of $3.5 \mathrm{~kg} /$ min $(3 \mathrm{kPa}$ at a milk flow of $2 \mathrm{~kg} / \mathrm{min})$ to a minimum vacuum of $33 \mathrm{kPa}$. The milk line used for treatment 1 was installed at a low level, defined by ISO 3918 (International Organization for Standardization, 2007). Treatment 1 was considered as the control because it represents frequently observed vacuum conditions in routine milkings. To test the effect of a very high system vacuum combined with a normal minimum vacuum during peak milk flow on milking performance and teat condition, treatment 2 used a system vacuum 
of $50 \mathrm{kPa}$, and the vacuum drop at a milk flow of 3.5 $\mathrm{kg} / \mathrm{min}$ was adjusted to $16 \mathrm{kPa}(11 \mathrm{kPa}$ at a milk flow of $2 \mathrm{~kg} / \mathrm{min}$ ) to achieve a minimum vacuum of $34 \mathrm{kPa}$ during milking (i.e., close to treatment 1). For treatment 3 , a system vacuum of $42 \mathrm{kPa}$ was used (as in treatment 1). However, the vacuum drop was set to 18 $\mathrm{kPa}$ at a milk flow of $2.5 \mathrm{~kg} / \mathrm{min}(16 \mathrm{kPa}$ at a milk flow of $2 \mathrm{~kg} / \mathrm{min}$ ) to achieve a very low minimum vacuum level of $24 \mathrm{kPa}$ at the teat end during peak milk flow, which was expected to be reduced in treatment 3 due to the resulting low vacuum. The milk line for treatments 2 and 3 was installed at $1.90 \mathrm{~m}$ above cow standing level, which corresponds to a high line milking system, defined by ISO 3918 (International Organization for Standardization, 2007).

\section{Technical Settings to Achieve the Attempted Vacuum Settings}

The used vacuum pump allowed to adjust the system vacuum to either 42 or $50 \mathrm{kPa}$. Milk flow induced vacuum drops were achieved by short plastic restriction pieces of $2 \mathrm{~cm}$ length in the long milk tube. Different diameters of restriction pieces were tested in a pre-trial to obtain the intended mean vacuum drops of 9,16 , and $18 \mathrm{kPa}$ at a milk flow of $3.5 \mathrm{~kg} / \mathrm{min}$. Finally, a restriction piece of $7 \mathrm{~mm}$ diameter was chosen for the experiment. For the vacuum drop of $9 \mathrm{kPa}$ at a milk flow of $3.5 \mathrm{~kg} / \mathrm{min}$, the low line system was used, whereas the high line system combined with the restrictions was shown to be suitable to achieve vacuum drops of 16 and $18 \mathrm{kPa}$ at a milk flow of 3.5 or $2.5 \mathrm{~kg} / \mathrm{min}$, respectively. Because the individual vacuum drop depends of the actual milk flow, and on the other hand affects milk flow, the settings had to be adjusted during the period of highest milk flow without considering a specific milk flow level. The resulting effect of each vacuum setting (system vacuum and vacuum drop) is shown in the Results section (Table 2).

\section{Milking Characteristics}

Milk flow was continuously recorded throughout the whole milking process. Milk flow was recorded by strain-gauge-based load cells of series type FXC 50 kg (Vetek Weighing AB, Väddö, Sweden), which were suspended to the milk recording jar. The weight of the milk jar was recorded at a frequency of $2 \mathrm{kHz}$ differentiated by time to obtain milk flow at a unit of kilograms per minute. A smoothed milk flow curve was obtained through the NI LabVIEW software (National Instruments GmbH, Ennetbaden, Switzerland) algorithm on the raw milk flow signal. The calibration of the recording system was repeatedly tested and had an offset of $<1 \%$. The continuously recorded milk flow curves were used to calculate the various milking characteristics. Their definitions are described in detail in Table 1.

\section{Ultrasonographic Measurements of Teat Condition}

Teat condition was measured after milking within 1 min after cluster detachment.

Longitudinal cross sections of the left front teat of each animal were performed by b-mode ultrasound with the teat emerged in a warm water bath as previously described by Weiss et al. (2004). A portable ultrasound unit (4Vet, Draminsky, Olsztyn, Poland) with a $60-\mathrm{mm}$ linear probe at a frequency of 5 to $10 \mathrm{MHz}$ was used for ultrasound scanning. The ultrasound images were evaluated for teat diameter, teat cistern diameter, and teat wall thickness. All measurements on ultrasound images were performed diametrically at $2 \mathrm{~cm}$ above the teat tip.

Table 1. Definitions of milking characteristics

\begin{tabular}{|c|c|c|}
\hline Characteristic & Abbreviation & Definition \\
\hline Total milk yield (kg) & TMY & $\begin{array}{l}\text { Yield of milk registered from cluster attachment to detachment (including strip } \\
\text { yield) }\end{array}$ \\
\hline Main milk yield (kg) & MMY & Amount of milk extracted during main milking time \\
\hline Strip yield (kg) & SY & $\begin{array}{l}\text { Amount of milk extracted by the milking machine and supported by hand } \\
\text { massage from the end of main milking time until cluster detachment }\end{array}$ \\
\hline Peak milk flow rate $(\mathrm{kg} / \mathrm{min})$ & PFR & $\begin{array}{l}\text { Maximum average milk flow during machine time, which was reached during a } \\
20 \text {-s period during milking. }\end{array}$ \\
\hline Main milk flow rate $(\mathrm{kg} / \mathrm{min})$ & MMF & Main milk yield/main milking time \\
\hline Average milk flow rate $(\mathrm{kg} / \mathrm{min})$ & AMF & $\begin{array}{l}\text { Total milk yield (yield registered from point of cluster attachment to } \\
\text { detachment)/machine-on time }\end{array}$ \\
\hline Total milking time (min) & TMT & $\begin{array}{l}\text { Time registered from moment of cluster attachment to detachment (including } \\
\text { stripping time) }\end{array}$ \\
\hline Main milking time (min) & MMT & Time from main milk flow $>200 \mathrm{~g} / \mathrm{min}$ to main milk flow $<200 \mathrm{~g} / \mathrm{min}$ \\
\hline Stripping time (min) & $\mathrm{ST}$ & Time needed for stripping (see strip yield) \\
\hline Time to peak flow rate $(\mathrm{min})$ & tPFR & Time from cluster attachment to peak milk flow \\
\hline
\end{tabular}




\section{Mathematical and Statistical Evaluations}

All data are presented as arithmetic means and standard error of the means. The SAS software (ed. 9.4, SAS Institute Inc., Cary, NC) was used for statistical analyses. Calculations were conducted with the mixed procedure of SAS. The model included cow as random factor and cow within treatment as repeated subjects. Differences of means were tested for significance with the Tukey-Kramer test and considered as significant if $P<0.05$.

The recorded milk flow curves were used to simulate the expected changes of milking characteristics at various other cluster detachment levels. Cluster detachment levels of 1,000, 800, 600, 400, and $200 \mathrm{~g}$, respectively, were selected for these simulations. Based hereupon relative milk yields (\%) obtained until detachment relative to total milk yield including stripping (TMY), milking time, and average milk flow (AMF) were estimated by using the EasyVIEW software (5.6, Intab, Stenkullen, Sweden). Because the estimates for the simulated detachment levels are all derived from the same original milk flow recording, only descriptive statistics (means \pm SEM) was calculated, and differences between simulated detachment levels and treatments were not tested for significance.

\section{RESULTS}

\section{Vacuum Conditions}

The system vacuum was adjusted to $42 \mathrm{kPa}$ in treatments 1 and 3 , and $50 \mathrm{kPa}$ in treatment 2, respectively. The adjustments of vacuum drops as tested in the pre-trial were confirmed during the main experiment. The attempted vacuum drops at the teat end through different restrictions and milk line height were achieved in all treatments. The minimum vacuum during peak milk flow was $33 \pm 0.1,34 \pm 0.2$, and $24 \pm 0.2 \mathrm{kPa}$ in treatments 1,2 , and 3 , respectively.

\section{Milking Characteristics}

Due to the different intervals between milkings, both TMY and amount of milk extracted during main milking time (MMY) were significantly $(P<0.05)$ higher at morning than at evening milkings (TMY: $15.8 \pm 0.22$ vs. $15.2 \pm 0.20 \mathrm{~kg}$; MMY: $15.2 \pm 0.21 \mathrm{~kg}$ vs. $14.6 \pm 0.19$ $\mathrm{kg}$, respectively). The amount of milk extracted by the milking machine and supported by hand massage from the end of main milking time until cluster detachment (SY) did not differ between morning and evening milkings (data not shown). The maximum average milk flow during machine time, which was reached during a 20-s period during milking (PFR), main milk yield/main milking time (MMF), and AMF did not differ between morning and evening milkings. Due to the higher milk yield at morning than evening milkings, time registered from moment of cluster attachment to detachment, including stripping time (TMT), and time from main milk flow $>200 \mathrm{~g} / \mathrm{min}$ to main milk flow $<200 \mathrm{~g} / \mathrm{min}$ (MMT) were significantly $(P<0.05)$ longer at morning than at evening milkings (TMT $=9.09 \pm 0.16$ vs. $8.79 \pm 0.16 \mathrm{~min} ; \mathrm{MMT}=7.41 \pm 0.15$ vs. $7.19 \pm 0.15$ min), whereas the time needed for stripping did not differ between morning and evening milkings.

Milking characteristics for the different treatments are shown on Table 2. The TMY and MMY did not differ $(P>0.05)$ between the 3 treatments. However, SY was significantly lower in treatment 3 than in treatments 1 and $2(P<0.05)$. The PFR, MMF, and AMF were significantly lower in treatment 3 than in treatments 1 and 2. Consequently, TMT and MMT were longer in treatment 3 than in treatments 1 and 2 . The time needed for stripping and time from cluster attachment to peak milk flow did not differ between the treatments (see Table 2).

The milking characteristics at different simulated cluster detachment levels are shown on Table 3. Early detachment at up to a milk flow of $1,000 \mathrm{~g} / \mathrm{min}$ would increase AMF dramatically as compared with $200 \mathrm{~g} /$ min, and thus shorten milking time in all treatments by up to $1.5 \mathrm{~min}$. Already at a detachment at 1,000 or $800 \mathrm{~g} / \mathrm{min} 93$ to $94 \%$ of the TMY would have been obtained, similarly in all treatments, and at lower detachment levels of 600,400 , or $200 \mathrm{~g} / \mathrm{min}$ only a little more (up to $96 \%$ ) of the milk stored in the udder would have been obtained without an obvious difference between treatments, except for treatment 3 with a very low minimum teat end vacuum and long milking time when up to $97 \%$ of the milk could be obtained with detachment at $200 \mathrm{~g} / \mathrm{min}$ without stripping (see Table 2).

\section{Ultrasound Measurements}

Results of ultrasound teat cross sections are shown in Table 4 . The teat diameter did not differ $(P>0.05)$ between the 3 treatments. However, teat cistern diameter at $2 \mathrm{~cm}$ above the teat tip was significantly smaller in treatment 2 compared with treatments 1 and 3 , respectively. Teat wall thickness was significantly larger in treatment 2 than in treatments 1 and $3(P<0.05)$. The numerically smallest teat wall thickness was measured in treatment 3 .

\section{DISCUSSION}

The current results demonstrate considerable effects of the different vacuum levels on milking performance 
Table 2. Means \pm standard error of the mean of milking characteristics for all treatments ${ }^{1}$

\begin{tabular}{lccc}
\hline Characteristic & Treatment 1 & Treatment 2 & Treatment 3 \\
\hline TMY (kg) & $15.4 \pm 0.26$ & $15.6 \pm 0.27$ & $15.4 \pm 0.25$ \\
MMY (kg) & $14.8 \pm 0.25$ & $14.9 \pm 0.26$ & $14.9 \pm 0.25$ \\
SY (kg) & $0.65 \pm 0.05^{\mathrm{a}}$ & $0.68 \pm 0.04^{\mathrm{a}}$ & $0.49 \pm 0.04^{\mathrm{b}}$ \\
PFR (kg/min) & $3.27 \pm 0.05^{\mathrm{a}}$ & $3.34 \pm 0.05^{\mathrm{a}}$ & $2.45 \pm 0.04^{\mathrm{b}}$ \\
MMF (kg/min) & $2.27 \pm 0.04^{\mathrm{a}}$ & $2.26 \pm 0.04^{\mathrm{a}}$ & $1.75 \pm 0.03^{\mathrm{b}}$ \\
AMF (kg/min) & $1.89 \pm 0.03^{\mathrm{a}}$ & $1.89 \pm 0.03^{\mathrm{a}}$ & $1.52 \pm 0.02^{\mathrm{b}}$ \\
TMT (min) & $8.28 \pm 0.17^{\mathrm{a}}$ & $8.30 \pm 0.13^{\mathrm{a}}$ & $10.2 \pm 0.18^{\mathrm{b}}$ \\
MMT (min) & $6.63 \pm 0.15^{\mathrm{a}}$ & $6.63 \pm 0.10^{\mathrm{a}}$ & $8.65 \pm 0.19^{\mathrm{b}}$ \\
ST (min) & $1.65 \pm 0.09$ & $1.67 \pm 0.08$ & $1.59 \pm 0.10$ \\
tPFR (min) & $2.77 \pm 0.13$ & $2.61 \pm 0.13$ & $2.77 \pm 0.19$ \\
\hline
\end{tabular}

$\overline{\mathrm{a}, \mathrm{b}}$ Means with different superscript letters within row differ significantly $(P<0.05)$.

${ }^{1}$ Treatment 1: system vacuum $=42 \mathrm{kPa}$, minimum claw vacuum $=33 \mathrm{kPa}$. Treatment 2 : system vacuum $=$ $50 \mathrm{kPa}$, minimum claw vacuum $=34 \mathrm{kPa}$. Treatment 3 : system vacuum $=42 \mathrm{kPa}$, minimum claw vacuum $=$ $24 \mathrm{kPa}$.

and partly also on teat condition (i.e., teat wall thickness).

The observed higher milk yields (TMY, MMY) at morning than evening milkings were expected due to the longer intervals before the morning milkings compared with evening milkings (13 vs. $11 \mathrm{~h}$, respectively). Consequently, the higher amount of milk at morning milkings caused a longer milking time (TMT, MMT), but did not influence milk flow levels (AMF, PFR) or stripping. This confirms that the amount of available milk stored in the udder effects mainly the duration of milk flow, whereas the milk flow level per se is mainly influenced by the anatomical characteristics of the udder and teat (Bruckmaier et al., 1991; Mayer et al., 1991).

All treatments used were suitable for an adequate emptying of the udder, as shown by the absence of significant differences of TMY and MMY between the 3 treatments. Only SY was slightly elevated in treatment
2 and significantly reduced in treatment 3 as compared with treatment 1 , respectively, indicating that the spontaneous udder emptying at high system vacuum levels is at least slightly compromised, whereas low vacuum levels are advantageous concerning the completeness of milk removal. A negative effect of high vacuum levels on the completeness of milk removal is supposed to occur mainly toward the end of milking when milk flow decreases and the vacuum drop disappears gradually, thus causing the full system vacuum acting on the teat (Besier et al., 2016). The currently available scientific literature is discussing the incidence of a preterm climbing of the cluster, which was not tested explicitly in this study, but needs to be considered as well. This effect is enforced by increasing vacuum toward the end of milking when simultaneously the teat is incompletely refilled with milk during the liner-closed phases of pulsation, because of the low remaining intra-cisternal pressure. The reduced refill of the teat is also the reason for a

Table 3. Estimates of different simulated detachment levels: percentage of main milk yield (percent_mmy $\mathrm{x}_{\mathrm{x}}$ ), time $\left(t_{x}\right)$, and average milk flow $\left(\mathrm{AMF}_{\mathrm{x}}\right)^{1}$

\begin{tabular}{lccc}
\hline Item & Treatment 1 & Treatment 2 & Treatment 3 \\
\hline percent_mmy & $93.1 \pm 0.4$ & $93.0 \pm 0.3$ & $92.9 \pm 0.5$ \\
percent_mmy $(\%)$ & $93.5 \pm 0.4$ & $93.4 \pm 0.3$ & $94.0 \pm 0.4$ \\
percent_mmy $(\%)$ & $94.1 \pm 0.3$ & $94.2 \pm 0.3$ & $95.0 \pm 0.3$ \\
percent_mmy $(\%)$ & $95.1 \pm 0.3$ & $94.7 \pm 0.3$ & $95.9 \pm 0.3$ \\
percent_mmy $(\%)$ & $95.8 \pm 0.3$ & $95.7 \pm 0.2$ & $96.8 \pm 0.2$ \\
$t_{1000}($ min) & $5.4 \pm 0.1$ & $5.3 \pm 0.1$ & $7.1 \pm 0.1$ \\
$t_{800}(\min )$ & $5.5 \pm 0.1$ & $5.4 \pm 0.1$ & $7.3 \pm 0.1$ \\
$t_{600}(\min )$ & $5.7 \pm 0.1$ & $5.6 \pm 0.1$ & $7.6 \pm 0.1$ \\
$t_{400}(\min )$ & $6.1 \pm 0.2$ & $5.8 \pm 0.11$ & $7.9 \pm 0.2$ \\
$t_{200}(\min )$ & $6.7 \pm 0.2$ & $6.6 \pm 0.1$ & $8.7 \pm 0.2$ \\
AMF $_{1000}(\mathrm{~kg} / \mathrm{min})$ & $2.70 \pm 0.04$ & $2.76 \pm 0.03$ & $2.04 \pm 0.03$ \\
$\mathrm{AMF}_{800}(\mathrm{~kg} / \mathrm{min})$ & $2.66 \pm 0.04$ & $2.72 \pm 0.03$ & $2.00 \pm 0.03$ \\
$\mathrm{AMF}_{600}(\mathrm{~kg} / \mathrm{min})$ & $2.60 \pm 0.04$ & $2.64 \pm 0.04$ & $1.96 \pm 0.03$ \\
$\mathrm{AMF}_{400}(\mathrm{~kg} / \mathrm{min})$ & $2.50 \pm 0.05$ & $2.56 \pm 0.04$ & $1.90 \pm 0.03$ \\
$\mathrm{AMF}_{200}(\mathrm{~kg} / \mathrm{min})$ & $2.27 \pm 0.04$ & $2.27 \pm 0.03$ & $1.76 \pm 0.03$ \\
\hline
\end{tabular}

${ }^{1}$ Treatment $1:$ system vacuum $=42 \mathrm{kPa}$, minimum claw vacuum $=33 \mathrm{kPa}$. Treatment $2:$ system vacuum $=$ $50 \mathrm{kPa}$, minimum claw vacuum $=34 \mathrm{kPa}$. Treatment 3 : system vacuum $=42 \mathrm{kPa}$, minimum claw vacuum $=$ $24 \mathrm{kPa}$. 
Table 4. Means \pm standard error of the mean of ultrasound measurements ${ }^{1}$

\begin{tabular}{lccc}
\hline Measure & Treatment 1 & Treatment 2 & Treatment 3 \\
\hline Teat diameter $(\mathrm{mm})$ & $23.2 \pm 0.28$ & $23.2 \pm 0.23$ & $22.9 \pm 0.22$ \\
Cistern diameter $(\mathrm{mm})$ & $6.98 \pm 0.30^{\mathrm{a}}$ & $6.32 \pm 0.28^{\mathrm{b}}$ & $6.97 \pm 0.30^{\mathrm{a}}$ \\
Teat wall thickness $(\mathrm{mm})$ & $8.10 \pm 0.17^{\mathrm{a}}$ & $8.42 \pm 0.18^{\mathrm{b}}$ & $7.95 \pm 0.17^{\mathrm{a}}$ \\
\hline
\end{tabular}

${ }^{\mathrm{a}, \mathrm{b}}$ Means with different superscript letters within row differ significantly $(P<0.05)$.

${ }^{1}$ Treatment 1: system vacuum $=42 \mathrm{kPa}$, minimum claw vacuum $=33 \mathrm{kPa}$. Treatment 2 : system vacuum $=$ $50 \mathrm{kPa}$, minimum claw vacuum $=34 \mathrm{kPa}$. Treatment 3 : system vacuum $=42 \mathrm{kPa}$, minimum claw vacuum $=$ $24 \mathrm{kPa}$.

reduced friction between teat and barrel (Mein et al., 1973a,b), causing a deeper penetration of the teat into the liner (Bothur and Wehowsky, 1978; Hamann, 1989).

Treatments had a clear effect on milk flow rates and hence milking times. Although AMF, MMF, and PFR did not differ between treatments 1 and 2 , all 3 milk flow traits were considerably and significantly lower in treatment 3 . This shows clearly that the minimum vacuum during main milk flow has a crucial influence on the milk flow rate, and not the system vacuum. The system vacuum was much higher in treatment 2 than treatment 1 , but the minimum vacuum during milking was similar. On the other hand, the system vacuum was identical in treatments 1 and 3 , but the more pronounced vacuum drop in treatment 3 led to a very low minimum vacuum during main milk flow, which obviously caused a reduction of milk flow rate. The differences of milk flow rates between treatments at a simultaneously similar milk yield directly caused the respective differences of milking times. Thus, TMT and MMT were not different between treatments 1 and 2, but much longer in treatment 3 . These results confirm earlier findings from other authors who found significantly higher milk flow rates and shorter milking times with increasing milking vacuum (Smith et al., 1974; Thomas et al., 1991; Rasmussen and Madsen, 2000). A low vacuum acting on the teat caused low milk flow rates at correspondingly long machine-on times in the current study. A potential further consequence of very low claw vacuum is also an increased frequency of liner slips (Rasmussen and Madsen, 2000).

The small differences of estimated results between different simulated detachment levels reflect the steep decline of the milk flow curve towards the end of milking as long as the duration of milk flow does not dramatically differ between quarters. Although the milk loss at early detachment is very low, the reduction of milking time appears to be considerable, and an early detachment should be considered under these circumstances. It can also be expected that a shorter machine-on time through early detachment reduces the mechanical effect on the teat in particular if the vacuum drop is diminished and the teat end vacuum approaches the level of system vacuum if milk flow becomes very low (not shown with the present experimental settings because no early detachment was present in this study). The obtained estimates are in accordance with an earlier study by Rasmussen (1993) who found an increase of AMF and teat condition if the cluster was detached at $400 \mathrm{~g} / \mathrm{min}$ instead of $200 \mathrm{~g} / \mathrm{min}$. Our estimates suggest that also higher detachment levels should be considered and experimentally tested.

A thickening of the teat tissue during milking, caused by the vacuum load on the teat, was observed in several studies using various methods for measurement (Langlois et al., 1981; Hamann and Mein, 1988; Hamann et al., 1993). A high teat-end vacuum especially at the end of milking is supposed to affect the teat tissue. Our current results of teat ultrasound cross-sectioning immediately after cluster detachment showed an increase of teat wall thickness and hence reduced teat cistern diameter in treatment 2 . Treatment 2 combined a high system vacuum of $50 \mathrm{kPa}$ (as commonly recommended for high line systems) with a similarly normal minimum teat-end vacuum during the milk flow plateau phase as in treatment 1. It is obvious that the high system vacuum affects the teat tissue as long as it acts on the teat, what happens only toward the end of milking when milk flow decreases or fully ceases in individual quarters. It is unlikely that the high system vacuum affects the teat very much at the start of milking unless the udder is not well prepared and milk flow is low or transiently interrupted before milk ejection occurs (Bruckmaier and Blum, 1996, 1998; Besier et al., 2016). In a well-stimulated udder, the milk flow increases immediately after the start of milking, which induces an immediate vacuum drop at the teat end. Therefore, the high system vacuum acts only for a very short time on the teat at the start of milking, and an important effect of the high vacuum is not expected. However, it is most obvious that the major effect of high vacuum on the teat tissue occurs toward the end of milking when milk flow decreases or ceases in some quarters. A reduction of the effect of high vacuum on the teat appears likely through early cluster detachment at the end of milking. The low pressure on the teat during the liner closed 
phase and hence the reduced massage effect in treatment 3 did not show a different teat tissue reaction than treatment 1 .

In conclusion, a high vacuum drop during milking leading to a teat-end vacuum below $30 \mathrm{kPa}$ causes a reduction of milk flow and hence long machine-on time. However, no obviously negative effect is present on udder emptying and load on the teat tissue. Because of the slow milking and an increased risk of liner slips (none observed in current study), a vacuum below $30 \mathrm{kPa}$ is not recommended under practical farming conditions. A high system vacuum seems to compensate for a (nonavoidable) vacuum drop and thus allows good milking performance. However, the risk of an effect on the teat is increased. A low massage effect through periods of low vacuum has apparently a much smaller effect on the teat tissue than a very high system vacuum.

Because the increased load on the teat tissue obviously occurs toward the end of milking, an early cluster detachment could be a way to reduce the load on the tissue without changes of the milk yield. Not surprisingly, the optimal milking performance and teat condition can be achieved if only a moderate vacuum drop occurs during peak milk flow. Therefore, the system vacuum does not need to be at a very high level, thus also keeping the effect on the teat low after milk flow has decreased or ceased at the end of milking. In addition, the simulated early cluster detachment based on the current milk flow curves allows the assumption that a detachment up to $600 \mathrm{~g} / \mathrm{min}$ does not cause a considerable loss of milk, but reduces machine-on time and effect on the tissue especially with high milking vacuum in the absence of a vacuum drop.

\section{REFERENCES}

Ambord, S., and R. M. Bruckmaier. 2010. Milk flow-dependent vacuum loss in high-line milking systems: Effects on milking characteristics and teat tissue condition. J. Dairy Sci. 93:3588-3594.

Baxter, E. S., P. M. Clarke, F. H. Dodd, and A. S. Foot. 1950. Factors affecting the rate of machine milking. J. Dairy Res. 17:117-127.

Besier, J., O. Lind, and R. M. Bruckmaier. 2016. Dynamics of teatend vacuum during machine milking: Types, causes and impacts on teat condition and udder health-A literature review. J. Appl. Anim. Res. 44:263-272.

Bothur, D., and G. Wehowsky. 1978. Untersuchungen über Ursache und Wirkung des Hochgleitens der Melkbecher an den Zitzen in der Endphase des Melkprozesses (Investigations about causes and consequences of teatcup climbing on teat condition at the end of milking). Mh. Vet. Med. 33:217-222.
Bruckmaier, R., H. Mayer, and D. Schams. 1991. Effects of alpha- and beta-adrenergic agonists on intramammary pressure and milk flow in dairy cows. J. Dairy Res. 58:411-419.

Bruckmaier, R. M., and J. W. Blum. 1996. Simultaneous recording of oxytocin release, milk ejection and milk flow during milking of dairy cows with and without prestimulation. J. Dairy Res. 63:201208.

Bruckmaier, R. M., and J. W. Blum. 1998. Oxytocin release and milk removal in ruminants. J. Dairy Sci. 81:939-949. (Review).

Hamann, J. 1989. Maschineller Milchentzug und Mastitis-Zum Einfluss des maschinellen Milchentzuges auf die Infektionsgefahr für die bovine Milchdrüse (Machine milking and mastitis - The influence of machine milking on infection risk of the bovine teat). Ferdinand Enke Verlag, Stuttgart, Germany.

Hamann, J., C. Burvenich, M. Mayntz, O. Osteras, and W. Haider. 1994. Machine-induced changes in the status of the bovine teat with respect to the new infection risk. IDF Bulletin 297:13-22.

Hamann, J., and G. A. Mein. 1988. Responses of the bovine teat to machine milking: Measurement of changes in thickness of the teat apex. J. Dairy Res. 55:331-338.

Hamann, J., G. A. Mein, and S. Wetzel. 1993. Teat tissue reactions to milking: Effects of vacuum level. J. Dairy Sci. 76:1040-1046.

International Organization for Standardization. 2007. ISO 3918Milking machine installations-Vocabulary. International Organization for Standardization, Geneva, Switzerland.

Isaksson, A., and O. Lind. 1992. Teat reactions in cows associated with machine milking. J. Vet. Med. A 39:282-288.

Langlois, B. E., J. S. Cox Jr., R. H. Hemken, and J. Nicolai Jr.. 1981. Milking vacuum influencing indicators of udder health. J. Dairy Sci. 64:1837-1842.

Mayer, H., R. Bruckmaier, and D. Schams. 1991. Lactational changes in oxytocin release, intramammary pressure and milking characteristics in dairy cows. J. Dairy Res. 58:159-169.

Mein, G. A., C. C. Thiel, and D. N. Akam. 1973a. Mechanics of the teat and teatcup liner during milking: Information from radiographs. J. Dairy Res. 40:179-189.

Mein, G. A., C. C. Thiel, D. R. Westgarth, and R. J. Fulford. 1973b. Friction between the teat and teatcup liner during milking. J. Dairy Res. 40:191-206.

Rasmussen, M. D. 1993. Influence of switch level of automatic cluster removers on milking performance and udder health. J. Dairy Res. 60:287-297.

Rasmussen, M. D., and N. P. Madsen. 2000. Effects of milkline vacuum, pulsator airline vacuum, and cluster weight on milk yield, teat condition, and udder health. J. Dairy Sci. 83:77-84.

Smith, J. W., R. H. Miller, N. W. Hooven Jr., and E. D. Moore. 1974. Sources of variation in milk flow characteristics. J. Dairy Sci. 57:1355-1363.

Spencer, S. B., and L. R. Jones. 2000. Liner wall movement and vacuum measured by data acquisition. J. Dairy Sci. 83:1110-1114.

Stewart, W. E., and L. H. Schultz. 1958. The rate of machine milking of dairy cows. II. Effect of vacuum and pulsation rate. J. Dairy Sci. 41:849-856

Thomas, C. V., D. K. Force, and D. H. Bremel. 1991. Effects of pulsation ratio, pulsation rate, and teatcup liner design on milking rate and milk production. J. Dairy Sci. 74:1243-1249.

Weiss, D., M. Weinfurtner, and R. M. Bruckmaier. 2004. Teat anatomy and its relationship with quarter and udder milk flow characteristics in dairy cows. J. Dairy Sci. 87:3280-3289.

Zecconi, A., J. Hamann, V. Bronzo, and G. Ruffo. 1992. Machineinduced teat tissue reactions and infection risk in a dairy herd free from contagious mastitis pathogens. J. Dairy Res. 59:265-271. 